\title{
Analysis of thermal control and heat accounting economic convenience in typical Italian housing unit and climatic zones
}

\author{
Stefano Bergero ${ }^{1 *}$, Paolo Cavalletti ${ }^{2}$, Maurizio Michelini ${ }^{3}$ \\ ${ }^{1}$ DAD, Department of Architectural and Design, Polytechnic School, University of Genova, \\ Stradone S. Agostino 37, Genova 16123, Italy \\ ${ }^{2}$ DIME, Department of Mechanical Engineering, Polytechnic School, University of Genova, Via \\ all' Opera Pia 15 A, Genova 16123, Italy \\ ${ }^{3}$ Professional Engineering Organization of Genoa, Piazza della Vittoria 11/15, Genova 16121, \\ Italy
}

Email: bergero@arch.unige.it

\begin{abstract}
The present paper deals with the application of the recent Italian energy regulation (Legislative Decree 102/2014, Italian transposition of Energy Efficiency Directive 2012/27/EU) which states as mandatory the installation of heat accounting systems for each housing unit in buildings served by central heating, cooling and domestic hot water systems, except in case of technical impossibility and economic inefficiency. Building energy need depends on the following main parameters: insulation level, climatic conditions which affects both transmission and ventilation heat losses, operating time characteristics, plant efficiency. If energy need is low, the related economic saving is low compared with the installation costs of thermoregulation and heat accounting systems. The aim of the present paper is to statistically study the economic advantage linked to the application of the Legislative Decree 102/2014, considering a typical Italian dwelling served by a central heating system. It is statistically possible that, in warmer climatic zones from A to D of the Italian territory, the installation of thermoregulation and metering of winter thermal energy doesn't have any economic advantage. On the contrary, an economic return is very likely in cooler climatic zones $\mathrm{E}$ and $\mathrm{F}$. The cost-benefits analysis is carried out according to the UNI EN 15459 standard in terms of SP and NPV indicators.
\end{abstract}

Keywords: Thermal Control, Heat Accounting, Cost-benefit Analysis, Directive 2012/27/UE.

\section{INTRODUCTION}

In Italy, there are almost 5 million condominium units with central heating and/or domestic hot water and/or cooling systems, where thermal energy is produced by a generator common to multiple apartments or buildings.

Before the entry into force of Legislative Decree 102/2014 [1] and its requirements, only few buildings possessed the possibility to withdraw and pay energy on the basis of actual consumption of individual users, as occurs in case of independent heating; costs were usually divided into fixed rates, proportional to the installed thermal power or to the radiant surface or to the property surface. This situation did not encourage energy savings in any way: for instance, by closing radiators when the house is empty or by improving the walls, windows, floors and roofs insulation. The user's virtuous behaviour was not refunded by a proportional individual economic benefit.

Temperature control and direct/indirect heat metering for individual apartments systems installation is always a good practice, regardless of the requirements contained in
Legislative Decree 102/2014, as amended by Legislative Decree 141/2016 [2]. In fact, the Presidential Decree 412/1993 (art. 7 par. 3) [3] already required that, since July 18, 1991, date of entry into force of Law 10/1991 [4], "new buildings must be designed and built to allow thermoregulation and heat metering for each apartment", and also that "new buildings service thermal plants, whose building permit is issued after June 30, 2000, must be equipped with temperature control and heat accounting system for each housing unit".

Not surprisingly, Law 10/1991 (art. 26, par. 5), in identifying building works subject to technical report, as required by art. 28, provides that "for innovations related to the adoption of the thermoregulation and heat metering systems and for the related allocation of heating costs according to actual consumptions, the condominium assembly decides by majority vote, notwithstanding civil code articles 1120 and 1136". The above provision was amended by Law 220/2012 (art. 28 par. 2) [5], concerning amendment to condominium regulation, by ordering that the condominium assembly decides by the majority provided for article 1120, paragraph 2 of the Civil Code, "the resolutions must always be approved 
with a number of votes representing the majority of the present people and at least half of the building ownership".

However, Directive 2012/27/EU [6] and its implementing Italian Legislative Decree 102/2014, set great caution in imposing specific obligations for older buildings and legitimately not equipped with temperature control and heat metering devices. If the plant adjustment interventions are not paid back by related energy savings, e.g. they are not "efficient in terms of costs", they are excluded from the obligation: the evaluation is referred to the cost-benefit analysis methodology, evaluated over the devices lifetime, according to UNI EN 15459 [7] standard.

In point, the Legislative Decree $102 / 2014$ is very clear: if a qualified expert in a technical report states that there is not efficiency in terms of costs, devices installation becomes optional and penalties do not apply. This exclusion joins the economic saving private interest with the public one of reducing energy consumption, so to promote good behaviours, motivated by the awareness to save money or to have a more flexible plant management.

A study published in the $3^{\text {rd }}$ ANACI-CENSIS Report [8] asserts that the $34.4 \%$ of the respondents citizens, interviewed after installing the heat metering systems, has indicated that it has saved nothing, or even to have spent more.

Since building energy need depends directly on insulation level, climatic conditions which affects both transmission and ventilation heat losses, operating time characteristics (e.g. holyday houses in tourist winter or summer places) and plant efficiency, the lower the energy amount demand is, the lower is the related energy and economic saving $[9,10]$.

In the present paper only the indirect metering system, which is the most common in Italy, and the effect of climatic conditions are considered; the other parameters influence will be taken into account in future researches.

Italy is divided in six climatic zones from $\mathrm{A}$ to $\mathrm{F}$ on the basis on the heating degree days (HDD), as reported in Table 1 . The $2,100 \mathrm{HDD}$ value (upper limit of the $\mathrm{D}$ zone) is considered the higher level of the moderate climate: in this condition, the average seasonal (winter) indoor-to-outdoor temperature difference is about $12.6^{\circ} \mathrm{C}$

Energy efficiency improvement of a building plant located in $\mathrm{F}$ climatic zone determines higher annual energy savings compared to the same improvement performed in zone A; in the latter case, the adjustment costs are not easily covered by the related savings owing to lower energy consumption.

Even if no legal obligation is set, temperature control and heat metering devices installation is always to be taken into consideration, since the cost effectiveness is estimated using statistical data and it doesn't consider any incentives in force. Furthermore, if the user is properly trained about temperature control devices use, real energy and economic savings can be even greater.

In the paper, cost-benefit analysis is carried out on a large scale and on statistical basis in order to demonstrate the economic impact of thermoregulation and heat accounting devices installation, referring to the average Italian housing unit and considering both the presence or the absence of taxfree discount nowadays available. The analysis has been performed through calculation of two indicators: the simple payback period (SP) and the net present value (NPV).

\section{NATIONAL DATA CONCERNING CENTRAL} HEATING IN BUILDINGS

This research is based on the following data on national scale.

- Total number of dwellings in Italy: 31,208,161, source ISTAT 2011 [11].

- Total area of housing in Italy: 2,396,691,555 $\mathrm{m}^{2}$, source ISTAT 2011 [11].

- Average size of a dwelling: 2,396,691,555 / 31,208,161 = $76.8 \mathrm{~m}^{2}$.

- Average number of rooms per dwelling: 4.45, source ISTAT 2011 [11].

- Percentage of dwellings served by central heating: $15.7 \%$, source ISTAT 2011 [11].

- Number of dwellings served by central heating: $31,208,161 \times 0.157=4,899,681$.

- Number of radiators related to central heating: 4,899,681 $\times 4.45=21,803,580$.

- Average number of dwellings per building: 30 [12].

- Average annual charge for residential energy consumption, including electricity: 1,724 €, source ISTAT 2011 [11] (1,635 $€$ in 2011 , actualized to 2016 by ISTAT index of 1.055 .).

- Average annual electricity charge per dwelling: $613 €$, source ISTAT 2011 [11] (581 $€$ in 2011, actualized to 2016 by ISTAT index of 1.055).

- Average annual heating cost per dwelling: 1,724 - $613=$ $1,111 €$

Italian population distribution in different climatic zones is shown in Table 1 [13]. The E climatic zone is widely prevalent in terms of population.

Table 1. Italian population distribution in different climatic zones

\begin{tabular}{|c|c|c|c|c|c|c|}
\hline & \multicolumn{7}{|c|}{ Climatic Zone } \\
\cline { 2 - 7 } & $\mathrm{A}$ & $\mathrm{B}$ & $\mathrm{C}$ & $\mathrm{D}$ & $\mathrm{E}$ & $\mathrm{F}$ \\
\hline $\mathrm{HDD}$ & $<600$ & $600-$ & $900-$ & $1,400-$ & $2,100-$ & $>3,000$ \\
{$\left[{ }^{\circ} \mathrm{C} \times \mathrm{d}\right]$} & & 900 & 1,400 & 2,100 & 3,000 & \\
\hline $\begin{array}{c}\text { Population } \\
\text { (Thousands) }\end{array}$ & 23 & 3,193 & 12,496 & 14,616 & 25,962 & 1,598 \\
\hline $\begin{array}{c}\text { Distribution } \\
{[\%]}\end{array}$ & 0.03 & 5.52 & 21.59 & 25.25 & 44.85 & 2.76 \\
\hline
\end{tabular}

\section{EVALUATION OF TEMPERATURE CONTROL AND HEAT METERING DEVICES INSTALLATION FOR THE AVERAGE BUILDING UNIT}

Table 2 shows the estimated costs for temperature control and heat metering devices installation for the average building unit, characterized by $76.8 \mathrm{~m}^{2}$ useful area and 4.45 radiators (national average). It is set inside a building with 30 residential units (national average), served by a central heating system.

The calculation takes into account not only initial costs of thermostatic valves and heat cost allocators supplying and installation, but also costs related to the design, supervision, management, administration and to the supplying and installation of a variable speed circulator in the boiler room, VAT included. Operating, maintenance and disposal costs have been also considered, included reading charges to annually compute the costs share among users. 
Table 2. Cost evaluation for temperature control and heat metering devices installation for the average building unit

\section{Installation costs}

Average Building: 30 units, 4.45 radiator per unit; $76.8 \mathrm{~m}^{2}$ per unit

Ratio bicirculator cost (up to 0.8 bar, $12 \mathrm{~m}^{3} / \mathrm{h}$ )

Regione Liguria price list code 40.A10.B10.030 (VAT 10\%)

$$
€ 1,916,48 \quad \text { x } \quad 1.1
$$

Ratio bicirculator installation cost

Regione Liguria price list code 40.E10.A10.020 (VAT 10\%)$$
€ 49.69 \quad \mathrm{x} \quad 1.1
$$

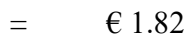

Regione Liguria price list code RU.M01.E01.010 (VAT 10\%)

$$
€ 36.28 \quad \mathrm{x} \quad 1.1 \quad \mathrm{x}
$$

Thermostatic valve cost per 4.45 radiators

Regione Liguria price list code 40.F10.B10.010 (VAT 10\%)

$$
€ 32.71 \quad \mathrm{x} \quad 1.1 \quad \mathrm{x}
$$

Meter cost per 4.45 radiators

Average market cost (Ebay, Caleffi 720020 Monitor 2.0) (VAT 10\%)

$$
€ 40.19 \quad \mathrm{x} \quad 1.1 \quad \mathrm{x}
$$

Installation cost: thermostatic valve per 4.45 radiators

Regione Liguria price list code 75.B10.A50.020, (VAT 10\%)

$$
€ 35.98 \quad \mathrm{x} \quad 1.1 \quad \mathrm{x}
$$

$\mathrm{x}$

Installation cost: meter per 4.45 radiators

Regione Liguria price list code 30.E30.A05.010 (VAT 10\%)

$$
€ 10.47 \quad \mathrm{x} \quad 1.1 \quad \mathrm{x}
$$

Design, work supervision, audit, final test, condominium division calculation

Decree DM 140/2012, estimation costs (VAT 22\%, incidental charges 4\%)

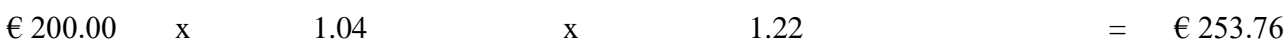

Meter reading charge, deferred on 10 years lifespan

Average market price (VAT 22\%)

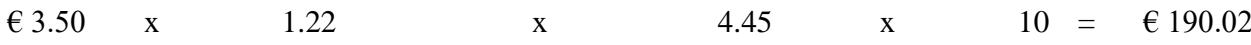

Maintenance, disposal charges deferred on 10 years lifespan

Circulator (UNI 15459, p. 31: 15 years; maintenance 2\% /year)

$$
€ 70.27 \quad \mathrm{x} \quad 0.02 \quad \mathrm{x} \quad 10=€ 14.05
$$

Thermostatic valves (UNI 15459, p. 31: 20 years; maintenance 1,5\%/year; disposal 5\%, deferred on 20 years)

$\begin{array}{rrcccccr}€ 160.12 & \mathrm{x} & 0.015 & \mathrm{x} & 10 & + & & € 24.02 \\ € 336.24 & \mathrm{x} & 0.05 & : & 20 & \mathrm{x} & 10 & € 8.41\end{array}$

Meters (10 Years - UNI 15459, p. 30, maintenance 1\%)

$$
€ 196.73 \quad \mathrm{x} \quad 0.01
$$

$\mathrm{x}$

10

Component Residual value (lifespan $>10$ years)

Circulator (5 years left)

: $20 \times 10=-€ 80.06$

Costs shown in Table 2 were obtained for some items from the Price List Works Plants and Construction 2016 of Liguria Region. The compatibility of these prices with those reported in the ENEA national analysis, reported in [14] and [15], have been checked. For the item "project, work supervision, testing, energy audit, allocation indicators" reference was made to the DM 140/2012 [16]. Maximum useful life of devices and the incidence of maintenance and disposal costs have been deducted from Annex A of UNI EN 15459 [7].

Meters have 10 years lifespan: the shortest among all 
considered components. In this time span, all costs, inflation effects and residual economic value of life for devices whose useful life is longer than 10 years (pumps and thermostatic valves) have been considered.

All inclusive, the charge cost per building unit is approximately $1,071 €$.

\section{COST-BENEFIT ANALYSIS}

\subsection{Simple payback time analysis}

In terms of building energy performance, the thermostatic valves installation leads to the change of the regulation subsystem, from "only climatic (compensation with outside feeler)" to "single room + climatic". This fact involves an improvement of the regulation efficiency, resulting in a $10 \div$ $16 \%$ reduction of building energy consumption. The lower range limit has been proposed by the ENEA Report RdS/PAR2014/081 analysis [14], while the upper limit is obtained by UNI/TS 11300-2:2014 application [17], related to the calculation of energy performance of apartment buildings served by traditional central heating systems.

Using the average annual cost for heating per dwelling estimated at $1,111 €$, it follows that the annual benefit deriving from the Legislative Decree 102/2014 adjustments, ranges between $111 \div 178 €$.

The simple payback period of the investment SP is determined as the ratio between the investment sum amounts, evaluated at time 0 , and the sum of yearly economic benefits, evaluated at time 0 , assuming economic and financial conditions as constant.

At first, no account is taken of tax deduction incentives: this assumption is necessary for the verification of efficiency in terms of costs provided by Legislative Decree 102/2014, since many citizens cannot benefit from tax deductions and therefore it is not reasonable to take them into account in a general audit valid for the whole building.

In the two above considered cases the simple payback time results:

$\mathrm{SP}_{10 \%}=1,071 / 111=9.6$ years

$\mathrm{SP}_{16 \%}=1,071 / 178=6.0$ years

If the condominium assembly decide to install the thermoregulation and metering devices regardless of legal obligations from Legislative Decree 102/2014, considering that they are as more useful if well used, beyond the savings statistical data used for the analysis of subjection, a 50\% tax deduction, as currently permitted by current national legislation in terms of building renovations, must be taken into account. In this case the SP time results:

$\mathrm{SP}_{10 \%}=1,071 / 2 / 111=4.8$ years

$\mathrm{SP}_{16 \%}=1,071 / 2 / 178=3.0$ years

Table 1 shows that about $48 \%$ Italian population lives in $\mathrm{E}$ and $\mathrm{F}$ climatic zones, while the remaining $52 \%$ in $\mathrm{A}$ to $\mathrm{D}$ zones. It follows that it is correct to attribute the heating average cost for dwelling, equal to 1,111 Euro (source ISTAT 2011), and consequently the above calculated return times SP, to an average building unit located in a town with a number of Heating Degrees Day HDD $=2,100$, set on the boundary between $\mathrm{D}$ and $\mathrm{E}$ zones.

So, assuming heating costs proportional to the Heating Degrees Day, it is possible to extrapolate heating costs and simple payback times for the other climatic zones, operating by analogy with the standardized assessment method of specific gross primary energy saving (SGS). This method has been applied to energy savings obtained for single reference physical unit in case of generation subsystem upgrading, as set in art. 4, Annex A of the AEEG Resolution 103/2003 [18].

Table 3 reports results considering both minimum and maximum benefit values resulting from the regulation efficiency improvement (10\% and 16\%). In Table 3 are also reported the coupling coefficients among the different climatic zones, the simple payback times in the absence and in the presence of the tax deduction incentive and the final technicaleconomic investment efficiency evaluation. It has been assumed as convenient if SP $<10$ years (minimum components lifespan).

The result shows that statistically:

- in A and B climatic zones it is likely to demonstrate there is no efficiency in terms of costs, regardless of incentives;

- in C climatic zone, without incentives, it is likely to demonstrate that there is no efficiency in terms of cost;

- in D climatic zone, without incentives, maybe efficiency in terms of cost or not;

- in $\mathrm{E}$ and $\mathrm{F}$ climatic zones it is unlikely to demonstrate that there is no efficiency in terms of costs, regardless of incentives.

Table 3. Simple payback time SP and economic efficiency in different climatic zones

\begin{tabular}{|c|c|c|cc|cc|}
\hline $\begin{array}{c}\text { Climatic } \\
\text { zone }\end{array}$ & $\begin{array}{c}\text { Adjustment } \\
\text { coefficient }\end{array}$ & & \multicolumn{2}{|c|}{$\begin{array}{c}\text { SP } \\
\text { no tax benefit }\end{array}$} & $\begin{array}{c}\text { SP } \\
\text { with tax benefit } \\
\text { SP }\end{array}$ & $\begin{array}{c}\text { SP } \\
\text { [years] }\end{array}$ \\
efficiency \\
\hline A-B & 0.21 & $\min$ & 45.9 & No & 22.9 & No \\
& & $\max$ & 28.7 & No & 14.3 & No \\
\hline C & 0.35 & $\min$ & 27.5 & No & 13.8 & No \\
& & $\max$ & 17.2 & No & 8.6 & Yes \\
\hline D & 0.64 & $\min$ & 15.1 & No & 7.5 & Yes \\
& & $\max$ & 9.4 & Yes & 4.7 & Yes \\
\hline E & 1.00 & $\min$ & 9.6 & Yes & 4.8 & Yes \\
& & $\max$ & 6.0 & Yes & 3.0 & Yes \\
\hline F & 1.39 & $\min$ & 6.9 & Yes & 3.5 & Yes \\
& & $\max$ & 4.3 & Yes & 2.2 & Yes \\
\hline
\end{tabular}

\subsection{Net present value analysis}

The simple payback time analysis is a simplified approach, since it doesn't consider the following factors:

- the inflation influences on cash flows in the years following the year in which the initial investment is carried out,

- the different money value at different times,

- the different energy costs during the evaluation period,

- the useful life of different devices,

- the maintenance, disposal and substitution costs during the evaluation period (running and replacements costs).

EU Regulation 244/2012 [19] defines the methodological framework for the determination of optimum energy buildings requirements both in technical and economic terms. The calculation of the investments cost effectiveness in buildings energy performance field is carried out by UNI EN 15459 [7] by the global cost method (GC). The global cost is the sum of the present value of the initial investments costs and the annual running, replacement and disposal (if applicable) costs, referred to the starting year. The evaluation is performed in 
terms of net present value (NPV). This methodology calculates the present value of an expected series of cash flows, not only adding them together for accounting purposes, but also actualizing them on the basis of the discount rate:

$N P V=I_{0}+\sum_{i=1}^{N} \frac{F C_{i}}{(1+r)^{i}}$

$\mathrm{N}=$ number of years of the evaluation period

$\mathrm{r}=$ discount rate.

$\mathrm{I}_{0}=$ initial cost

$\mathrm{FC}_{\mathrm{i}}=$ cash flow of the $\mathrm{i}$-year

EU Regulation 244/2012 establishes for residential buildings an evaluation period $\mathrm{N}=30$ year.

The discount rate $r$ must be calculated in real terms, i.e. it must be corrected in order to take into account of the inflation [20]:

$r=\frac{1+r^{\prime}}{(1+f)}-1$

$\mathrm{r}^{\prime}=$ official BCE discount rate, set equal to 0 , as stated in October 2016

$\mathrm{f}=$ annual inflation rate, set equal to $0.1 \%$, as stated by ISTAT, November 2016.

Table 4. Net present value NPV and economic efficiency in different climatic zones

\begin{tabular}{|c|c|c|c|c|c|c|}
\hline $\begin{array}{c}\text { Climatic } \\
\text { zone }\end{array}$ & $\begin{array}{l}\text { Adjustment } \\
\text { coefficient }\end{array}$ & & $\begin{array}{c}\text { NPV } \\
\text { no tax } \\
\text { NPV } \\
\text { [euro] }\end{array}$ & $\begin{array}{l}30 \text { years } \\
\text { benefit }\end{array}$ & $\begin{array}{l}\text { NPV } \\
\text { with ta } \\
\text { NPV } \\
\text { [euro] }\end{array}$ & $\begin{array}{l}30 \text { years } \\
\text { ax benefit } \\
\text { efficiency }\end{array}$ \\
\hline A-B & 0.21 & $\begin{array}{l}\min \\
\max \end{array}$ & $\begin{array}{l}-2,132 \\
-1,721 \\
\end{array}$ & $\begin{array}{l}\text { No } \\
\text { No } \\
\end{array}$ & \begin{tabular}{|l|}
$-1,670$ \\
$-1,259$ \\
\end{tabular} & $\begin{array}{l}\text { No } \\
\text { No }\end{array}$ \\
\hline $\mathrm{C}$ & 0.35 & $\begin{array}{l}\min \\
\max \end{array}$ & $\begin{array}{c}-1,675 \\
-989 \\
\end{array}$ & $\begin{array}{l}\text { No } \\
\text { No }\end{array}$ & $\begin{array}{c}-1,213 \\
-527\end{array}$ & $\begin{array}{l}\text { No } \\
\text { No }\end{array}$ \\
\hline D & 0.64 & $\begin{array}{l}\min \\
\max \end{array}$ & $\begin{array}{l}-728 \\
-527 \\
\end{array}$ & $\begin{array}{l}\text { No } \\
\text { No }\end{array}$ & $\begin{array}{c}-266 \\
989 \\
\end{array}$ & $\begin{array}{l}\text { No } \\
\text { Yes }\end{array}$ \\
\hline $\mathrm{E}$ & 1.00 & $\begin{array}{l}\min \\
\max \end{array}$ & $\begin{array}{c}448 \\
2,408 \\
\end{array}$ & $\begin{array}{l}\text { No } \\
\text { Yes }\end{array}$ & $\begin{array}{c}910 \\
2,870 \\
\end{array}$ & $\begin{array}{l}\text { Yes } \\
\text { Yes }\end{array}$ \\
\hline $\mathrm{F}$ & 1.39 & $\begin{array}{l}\min \\
\max \end{array}$ & $\begin{array}{l}1,722 \\
4,447\end{array}$ & $\begin{array}{l}\text { Yes } \\
\text { Yes }\end{array}$ & $\begin{array}{l}2,184 \\
4,908\end{array}$ & $\begin{array}{l}\text { Yes } \\
\text { Yes }\end{array}$ \\
\hline
\end{tabular}

The starting costs $\mathrm{I}_{0}$ and the $\mathrm{FC}_{\mathrm{i}}$ cash flows were calculated using data reported in Table 2, considering the useful life of devices according to UNI EN 15459, Annex A [7]. Cash flows in different years during the evaluation period were calculated upgrading replacement costs by the growth rate of the cost of components, assumed to be equal to $2 \%$ [21], while the installation and operating costs were reassessed according to inflation rate.

Results are reported in Table 4 for the different climatic zones, in the absence and in the presence of tax refund incentives and considering minimum and maximum savings obtainable by temperature control and heat metering devices implementation, as already explained in the previous section for SP evaluation.

Table 4 shows that the cost-benefit analysis in terms of NPV index leads essentially to the same conclusions obtained by SP evaluation. Without tax incentives, in A to D climatic zones it is possible to verify the absence of cost efficiency, being NPV value lower than the initial investment cost (approximately
$1,000 €)$; this evaluation has been made in accordance with UNI EN 15459 [7]. Such interventions maybe convenient in E and $\mathrm{F}$ climatic zones.

Figures 1 to 3 show the actualized cash flows in C, D, and E climatic zones, considering tax benefits (deduction of 50\%) and maximum energy saving of $16 \%$.

$[€]$

C Zone considering tax benefits and $16 \%$ energy savings

13557991113151719212325272931

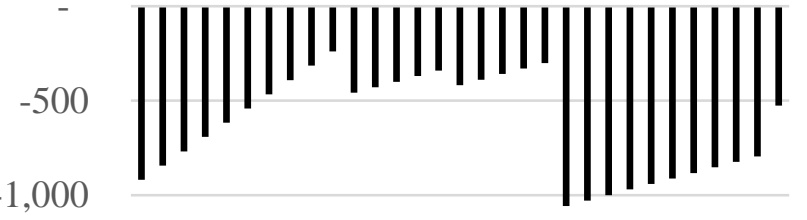

$-1,500$

Figure 1. Cumulated cash flow in $\mathrm{C}$ zone considering tax benefits and maximum energy saving of $16 \%$

\section{[€]}

\section{Zone considering tax benefits and $16 \%$ energy savings}

\section{1,500}

1,000

500

$-1,000$

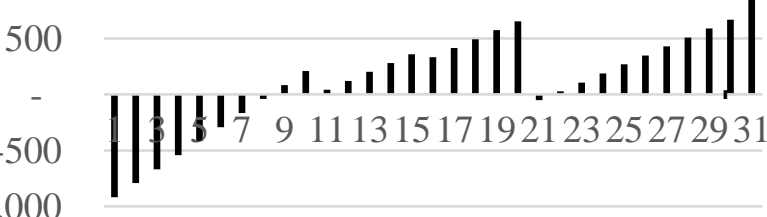

$-1,500$

Figure 2. Cumulated cash flow in D zone considering tax benefits and maximum energy saving of $16 \%$.

E Zone considering tax benefits and $16 \%$ energy savings

4,000

3,000

2,000

1,000

$-1,000$

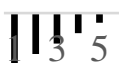

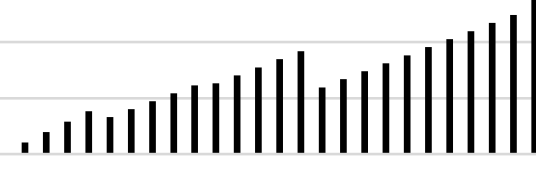

$-2,000$

Figure 3. Cumulated cash flow in E zone considering tax benefits and maximum energy saving of $16 \%$ 


\section{CONCLUSIONS}

In the four years since the publication of the Directive 2012/27/EU and in the two more elapsed since its transposition by the Legislative Decree 102/2014, Italian citizens have not perceived the utility, first of all, to verify by means of a technical evaluation, if the temperature control and heat metering devices installation was or was not efficient in terms of costs.

The present study shows that it is statistically possible that buildings located in warmer climatic zones (typically A, B, C and D) may be not subjected to the imposition of the Legislative Decree 102/2014. The imposition remains for about $50 \%$ of the whole national real estate located in colder ones (typically $\mathrm{E}$ and $\mathrm{F}$ ).

In cogency absence, owners could defer the immediate urge and could plan in subsequent years better interventions settled as part of a reasoned and affordable global energy refurbishment. Such behaviour would spread over time interventions and limit the anomaly of the market which, in the indifference of many, we are living in the last two years, with an exceptional concentration of economic interests in a limited period of time and on a few subjects. Indeed, many companies have ridden the inclination of the Italian population to not inquire about the original legislative text purposes and, using some law interpretation, push in the direction "of mandatory adjustment obligation at all costs".

Laws must be read so to satisfy the legislator's will, and it does not seem reasonable to think that the European Union intends to impose on Italy to adapt some 22 million radiators in two years, or better, in the few summer months when it is possible intervene with the heating systems off.

\section{ACKNOWLEDGMENT}

This research was funded by the research project PRA2016 - University of Genoa.

\section{REFERENCES}

[1] Implementation of Directive 2012/27/EU on energy efficiency, amending Directives 2009/125/EC and 2010/30/EU and repealing Directives 2004/8/EC and 2006/32/EC (2014). Legislative Decree 4 July 2014, No. 102 , Italy.

[2] Supplementary provisions to the Legislative Decree of 4 July 2014, No. 102, on the implementation of Directive 2012/27/EU on energy efficiency, amending Directive 2009/125/EC and 2010/30/EU and repealing Directive 2004/8/EC (2016). Legislative Decree 18 July 2016, No. 141 , Italy.

[3] Regulation laying down rules for design, installation, operation and maintenance of thermal installations of buildings for the purpose of containment of energy consumption, in implementation of art. 4 , par. 4 of the Law of 9 January 1991, No. 10 (1993). Decree of President of the Republic 26 August 1993, No. `412, Italy.

[4] Standards for implementation of the national energy plan for rational use of energy, energy saving and development of renewable energy sources (1991). Law 9 January 1991, No. 10, Italy.
[5] Changes to the condominium discipline in buildings (2012). Law 11 December 2012, No. 220, Italy.

[6] On energy efficiency, amending Directives 2009/125/EC and 2010/30/EU and repealing Directives 2004/8/EC and 2006/32/EC (2012). European Parliament, Directive 2012/27/EU of the European Parliament and of the Council of 25 October 2012.

[7] Energy performance of buildings. Economic evaluation procedure for energy systems in buildings (2008). Standard UNI EN 15459: 2008.

[8] Life in condominnium: litigation and energy saving, $3^{\text {rd }}$ Report ANACI-CENSIS 2009, Italy.

[9] Lo Cascio E., Ma Z., Borelli D., Schenone C. (2017). Residential building retrofit through numerical simulation: A case study, Energy Procedia, Vol. 111, pp. 91-100. DOI: 10.1016/j.egypro.2017.03.011

[10] Spoladore A., Borelli D., Devia F., Mora F., Schenone C. (2016). Model for forecasting residential heat demand based on natural gas consumption and energy performance indicators, Applied Energy, Vol. 182, pp. 488-499. DOI: 10.1016/j.apenergy.2016.08.122

[11] ISTAT (2011). 15th census of population and housing, Italy.

[12] From $w w w . c o n d o m i n i o . i t$, accessed on 2012.

[13] CRESME Ricerche S.p.A. (2012). Determining requirements and energy consumption of building-plant systems, Characterization of residential real estate park, ENEA Report RdS/2012/109, Italy.

[14] Biele E., Di Santo D., Tomassetti G. (2015). Analysis of the impact of thermostatic valves on the final consumption of users connected to the district heading networks of the mountain communities of the climatic zones E and F, ENEA Report Rds/ PAR2014/081, Italy.

[15] ENEA (2003). Energy saving in hausing, Italy.

[16] Regulation determining the parameters for the liquidation of remuneration for professions regularly monitored by the Ministry of Justice pursuant to Article 9 of Decree-Law No. 1 of 24 March 2012 (2012). Justice Ministry Decree 20 July 2012, No. 140, Italy.

[17] Energy Performance of Buildings, Part 2: Evaluation of primary energy need and of system efficiencies for space heating, domestic hot water production, ventilation and lighting for non-residential buildings (2014). Standard UNI/TS 11300-2:2014, Italy.

[18] AEEG (2003). Guidelines for the preparation, execution and evaluation of the projects referred to art. 5, par. 1, of the Ministerial Decrees of 24 April 2001 and the definition of the criteria and modalities for the issue of energy efficiency certificates, AEEG Resolution No. $103 / 2003$, Italy.

[19] Supplementing Directive 2010/31/EU of the European Parliament and of the Council on the energy performance of buildings by establishing a comparative methodology framework for calculating cost-optimal levels of minimum energy performance requirements for buildings and building elements (2012). European Commission, Commission Delegated Regulation (EU) 244/2012 of 16 January 2012.

[20] Corrado V., Ballarini I., Paduos S. (2013). Development of cost-optimal comparative methodology according to Directive 2010/31/EU, ENEA Report RdS/2013/144, Italy.

[21] ISTAT (2016). The Country Situation, ISTAT Report 2016, Italy. 
NOMENCLATURE

$\mathrm{f}$ inflation rate

NPV

$r$

net present value, $€$

FC cash flow, $€$

heating degree days, ${ }^{\circ} \mathrm{C} . \mathrm{d}$

Subscripts

I cost, $€$

0

time 0 